\title{
HEAT TOLERANCE \\ AND HEAT HARDENING IN CROP PLANTS MEASURED BY CHLOROPHYLL FLUORESCENCE
}

\author{
by \\ ROBERT M. SMILLIE \\ Plant Physiology Unit, CSIRO Division of Food Research and School of \\ Biological Sciences, Macquarie University, P.O. Box 52, North Ryde 2113 \\ Sydney, Australia \\ and \\ Department of Physiology, Carlsberg Laboratory, \\ Gamle Carlsberg Vej 10, DK-2500 Copenhagen Valby \\ and

\section{GREGORY C. GIBBONS} \\ Department of Biotechnology, Carlsberg Research Laboratory, \\ Gamle Carlsberg Vej 10, DK-2500 Copenhagen Valby
}

Keywords: Barley, bean, maize, papaya, pea, tomato, variable chlorophyll fluorescence

\begin{abstract}
Variable chlorophyll fluorescence $\left(F_{v}\right)$, indicative of the capacity for electron flow through photosystem II, decreased as leaves became heat injured. In leaves heated at a rate of $1{ }^{\circ} \mathrm{C}$ per minute, $F_{v}$ became undetectable above $43.3^{\circ} \mathrm{C}$ in barley, $44.2^{\circ} \mathrm{C}$ in pea, $45.2^{\circ} \mathrm{C}$ in bean, $45.3^{\circ} \mathrm{C}$ in tomato, $49.5^{\circ} \mathrm{C}$ in maize and $51.0^{\circ} \mathrm{C}$ in papaya. In heat hardened barley this temperature was increased by 6 to $9^{\circ} \mathrm{C}$ compared with unhardened barley. Measurement of $F_{v}$ in vivo provides a rapid method to monitor the onset of cellular heat injury, to rank plants in order of heat resistance and to follow heat hardening. It appears to be suitable for developing a mass screening test for heat tolerance.
\end{abstract}

\section{INTRODUCTION}

Plants inhabiting areas receiving high solar heat irradiation have evolved a remarkable variety of morphological and biochemical defences against the effects of high temperature. These attributes are not shared by most plants used for production of food and fibre. The ever present need to extend agriculture into regions receiving high insolation, together with the increasing salinity in established growing areas creating as 
it does pressures towards decreased transpirational rates with their attendant increases in leaf temperature, point to an urgent need for the selection and breeding of plants with increased tolerance to heat.

Non-destructive methods for comparing heat resistance and for following heat hardening are available and range from measurements of photosynthesis, $F_{0}$ fluorescence of chlorophyll, respiration, protein turnover and electrolyte leakage in intact tissue, to observations at the cellular level of vital staining, plasmolysis and protoplasmic streaming (2, 4, 14, 24, 29). Alternatively, assays of photochemical and enzymic activities in cell-free extracts can be used. None, however, is suitable as a method for screening large populations for heat resistance because of the complexity, time taken or subjective nature of the tests. We present here data to show that rate of rise in the variable component of chlorophy!l fuorescence in vivo is suitable for routine comparisons of heat resistance and treatments for heat hardening in plant physiological and horticultural studies, and for the development of a screening procedure for heat tolerance in crop plants.

\section{MATERIALS AND METHODS}

\subsection{Plant Material}

Leaves that had just reached full expansion were used for heating experiments and were taken from 2 to 3 week old plants of barley (Hordeum vulgare L., cv. Svalöfs Bonus), bean (Phaseolus vulgaris L.), maize (Zea mays L.) and pea (Pisum sativum L.). The plants were grown in a growth chamber with a 16 hour day at $28^{\circ} \mathrm{C}(6700 \mathrm{lux})$ and an 8 hour night at $24^{\circ} \mathrm{C}$. Leaves of Carica papaya $\mathrm{L}$. were taken from $2 \mathrm{~m}$ high plants growing in a growth room at $20^{\circ} \mathrm{C}$ under continuous light (1000 lux). Leaves of tomato (Lycopersicon esculentum Mill. var Supravite) were harvested from plants growing in a temperature controlled greenhouse $\left(25^{\circ} \mathrm{C} / 20^{\circ} \mathrm{C}\right)$.

Hordeum vulgare L. cv. Abyssinian was used for heat hardening experiments. Seeds were germinated for 2 days in running tap water and then transferred to a glass chamber surrounded by heated water and illuminated from above by white light (5000 lux, 12-hour day). Two heat hardening regimes were employed. In one, plants were grown at $37^{\circ} \mathrm{C}$ (day) $29^{\circ} \mathrm{C}$ (night) for 10 days; in the other, plants were grown at $35^{\circ} \mathrm{C} / 28^{\circ} \mathrm{C}$ for 4 days then at $40^{\circ} \mathrm{C} / 28^{\circ} \mathrm{C}$ for 2 days. Control plants were grown at $25^{\circ} \mathrm{C} / 19^{\circ} \mathrm{C}$. The primary leaf was used for all experiments.

\subsection{Chlorophyll fluorescence measurements during heating}

Chlorophyll fluorescence induction kinetics on sections or discs of leaves were recorded with a fluorometer Model SF-10 (Richard Brancker Research Ltd., Ottawa). The leaf material was placed on moist filter paper, abaxial surface down, on top of a fluted brass column standing in a water bath. The measuring unit of the fluorometer was positioned above the leaf tissue and separated from it by a layer of plastic film and an insulating $1-\mathrm{mm}$ thick nylon annular disc. The heating rate of the water bath was controlled at $1{ }^{\circ} \mathrm{C}$ per min using either a Heto gradient heating bath type 02 PG 623 UL (Heto Birkerød, Denmark) or a Braun 1480 Termomix and Braun 1490 temperature programmer. Leaf temperature was monitored with a thermocouple $\left( \pm 0.05^{\circ} \mathrm{C}\right.$ ). Because of heat losses in the system, leaf temperature increased at slightly less than $1{ }^{\circ} \mathrm{C}$ per min. Plants were dark-adapted for one hour before the leaves were used, and the irradiance, time and frequency of the fluorescence measurements chosen to allow for dark recovery between readings.

\section{RESULTS}

\subsection{Heat resistance}

Figure 1 illustrates changes in chlorophyll fluorescence induction kinetics during heating at $1{ }^{\circ} \mathrm{C}$ per minute of leaves of two cereals, barley and maize, which prefer a cool and a warm growing season, respectively. Immediately upon irradiation a leaf, chlorophyll fuorescence yield rose (fluorescence of constant yield at physiological temperatures, $F_{0}$ ), then after a slight delay the fluorescence yield rose again (fluorescence of variable yield, $F_{v}$ ) to reach a peak after about one second, and then slowly declined. With heating, as the leaf cells became heat stressed, two prominent changes occurred in the fluorescence 


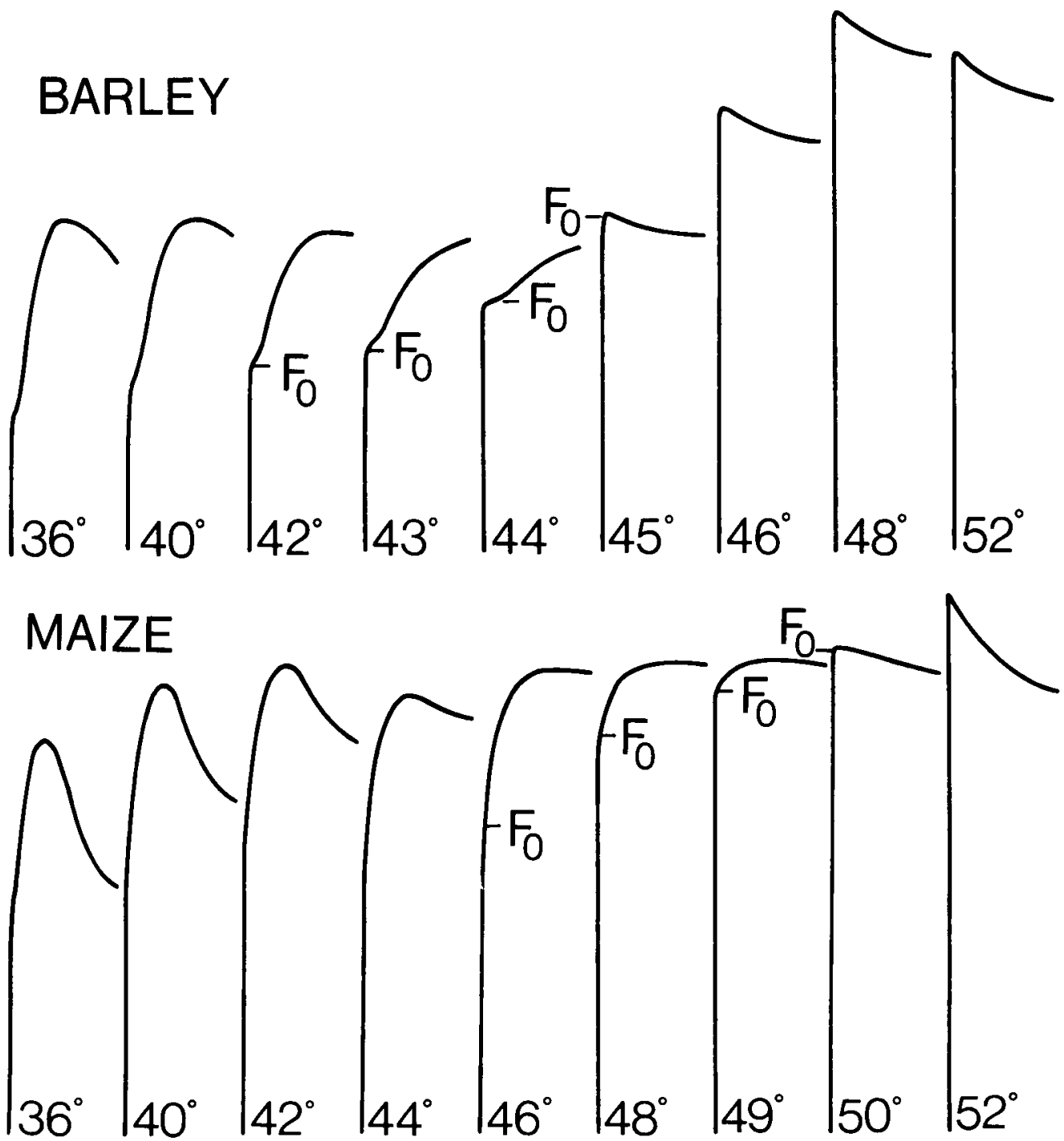

Figure 1. In vivo chlorophyll fluorescence changes in barley and maize secondary leaves heated at $1{ }^{\circ} \mathrm{C}$ per min.

Leaf temperature at the start of each fluorescence measurement (irradiation time: $2.8 \mathrm{~s} ; 11.2 \mu \mathrm{E} \mathrm{m} \mathrm{m}^{-2} \mathrm{~s}^{-1}$ ) is shown. The measuring unit of the fluorometer was positioned on the leaf one-third of the distance from the tip, avoiding the central vein.

induction kinetics. Firstly, the rate of rise and the magnitude of $F_{v}$, i.e., the increment in fluorescence yield above $F_{0}$, decreased to the point where it could no longer be measured and secondly, at somewhat higher temperatures, $F_{0}$ increased in size reaching a maximal value around $50^{\circ} \mathrm{C}$ or higher. These changes took place at higher temperatures in maize than in barley.
Fo also showed changes with temperature prior to the main increase commencing around $45^{\circ} \mathrm{C}$, the extent of the change varying with the leaves and species used. Studies with passionfruit leaves suggested that this change may be an indicator of early thermal damage (24).

The values for the maximal rate of the $F_{v}$ rise, $F_{V}$, and $F_{0}$ are plotted against leaf temperature in Figure 2 for the two cereals and four dicots. 


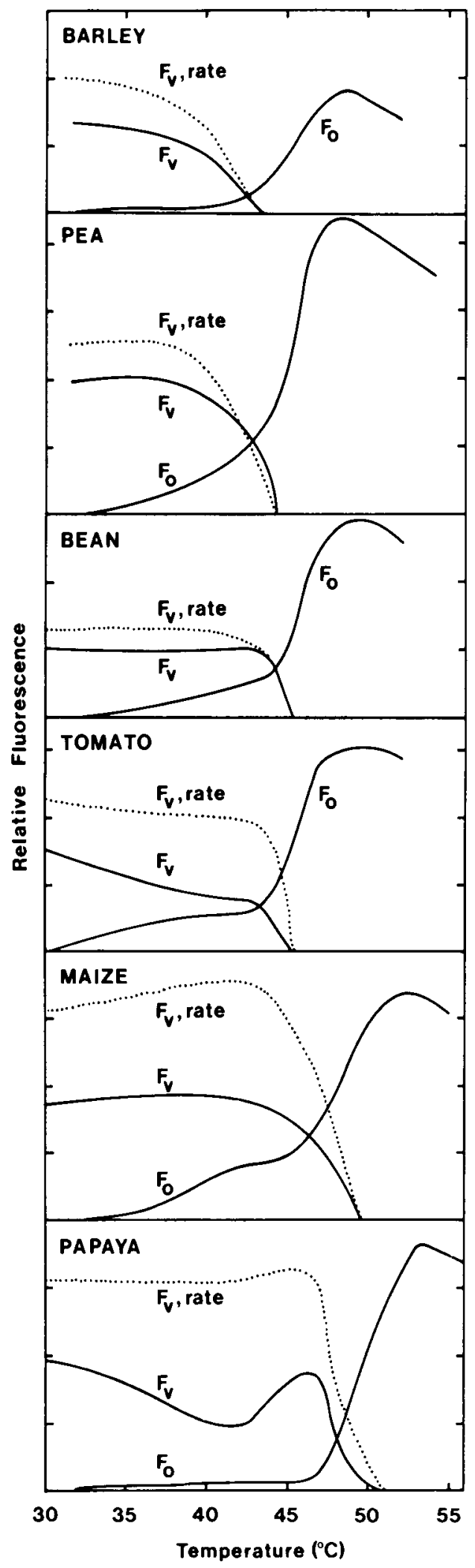

Figure 2. Changes in wconstant" fluorescence $\left(F_{0}\right)$, variable fluorescence $\left(F_{v}\right)$ and the rate of the $F_{v}$ rise (relative units $\mathrm{s}^{-1}$ ) in leaves heated at $1{ }^{\circ} \mathrm{C}$ per min.

A fluorescence measurement (irradiation time: 2.8 $\left.\mathrm{s} ; 11.2 \mu \mathrm{E} \mathrm{m}^{-2} \mathrm{~s}^{-1}\right)$ was taken with each degree rise in leaf temperature.

Again heating was at the rate of $1^{\circ} \mathrm{C}$ per minute. In the case of the pea leaf for example, both $F_{v}$ and the rate of the $F_{v}$ rise decreased above $38^{\circ} \mathrm{C}$ and could not be detected above $44.2^{\circ} \mathrm{C}$. $F_{o}$ increased slowly as the leaf temperature was raised, but above $43.9^{\circ} \mathrm{C}$ it increased more rapidly attaining a peak at $48^{\circ} \mathrm{C}$. The other plants tested showed similar trends with increasing leaf temperature; however, the quenching of $F_{v}$ and the main increase in $F_{0}$ did not occur at the same temperatures for each plant and clear differences in heat sensitivity between the six species were discernible. If the temperature at which the curve for the rate of the $F_{v}$ rise projected to zero was used as a basis of comparison of heat sensitivity, then barley and pea were the most sensitive, barley slightly more so than pea (Table I). Bean and tomato showed the same degree of heat sensitivity, but both were more resistant than either barley or pea. Maize was more resistant still and papaya (paw paw) the most resistant of all. The same ranking was obtained when the temperatures producing a $50 \%$ decrease in the rate of the $F_{v}$ rise were compared (Table I).

The temperature at which $\mathrm{F}_{\mathrm{o}}$ starts to increase rapidly has been used previously to compare the heat resistances of different plant species $(3,4$, $19,22,24,27)$. In references (24) and (27), this value corresponds to the temperature value $t_{2}$. This temperature value gave the same ranking as the one based on changes in $F_{v}$ (Table I). The temperature at which $F_{o}$ reached a peak gave a similar ranking, althought the temperature difference between the first 3 plants listed was only one degree.

\subsection{Heat hardening}

While growth temperature generally has little influence on heat tolerance, a specific hardening or change in heat tolerance can be elicited in many species by exposure to near lethal tempera- 
Table I

Temperatures producing chlorophyll fluorescence changes in leaves heated at $1^{\circ} \mathrm{C}$ per min.

\begin{tabular}{lcccc}
\hline Plant & $\begin{array}{c}50 \% \text { decrease } \\
\text { in Fv rise }\end{array}$ & $\begin{array}{c}F_{v} \text { rise } \\
=0\end{array}$ & $\begin{array}{c}\text { Start of } \mathrm{F}_{\mathrm{o}} \\
\text { increase }\end{array}$ & $\begin{array}{c}\mathrm{F}_{\mathrm{o}} \\
\text { maximum }\end{array}$ \\
\hline Barley & $40.7^{\circ} \mathrm{C}$ & $43.2^{\circ} \mathrm{C}$ & $42.7^{\circ} \mathrm{C}$ & $48.6^{\circ} \mathrm{C}$ \\
Pea & $42.1^{\circ} \mathrm{C}$ & $44.2^{\circ} \mathrm{C}$ & $43.9^{\circ} \mathrm{C}$ & $48.0^{\circ} \mathrm{C}$ \\
Bean & $44.3^{\circ} \mathrm{C}$ & $45.2^{\circ} \mathrm{C}$ & $44.5^{\circ} \mathrm{C}$ & $49.0^{\circ} \mathrm{C}$ \\
Tomato & $44.9^{\circ} \mathrm{C}$ & $45.3^{\circ} \mathrm{C}$ & $44.0^{\circ} \mathrm{C}$ & $50.0^{\circ} \mathrm{C}$ \\
Maize & $47.3^{\circ} \mathrm{C}$ & $49.5^{\circ} \mathrm{C}$ & $46.2^{\circ} \mathrm{C}$ & $52.5^{\circ} \mathrm{C}$ \\
Papaya & $47.9^{\circ} \mathrm{C}$ & $51.0^{\circ} \mathrm{C}$ & $47.0^{\circ} \mathrm{C}$ & $53.5^{\circ} \mathrm{C}$ \\
\hline Temperature & $7.2^{\circ} \mathrm{C}$ & $7.9^{\circ} \mathrm{C}$ & & \\
range & & $4.3^{\circ} \mathrm{C}$ & $5.5^{\circ} \mathrm{C}$ \\
\hline
\end{tabular}

* temperature at which the main increase in $F_{0}$ begins, determined as described by SCHREIBER and BerRY (29).

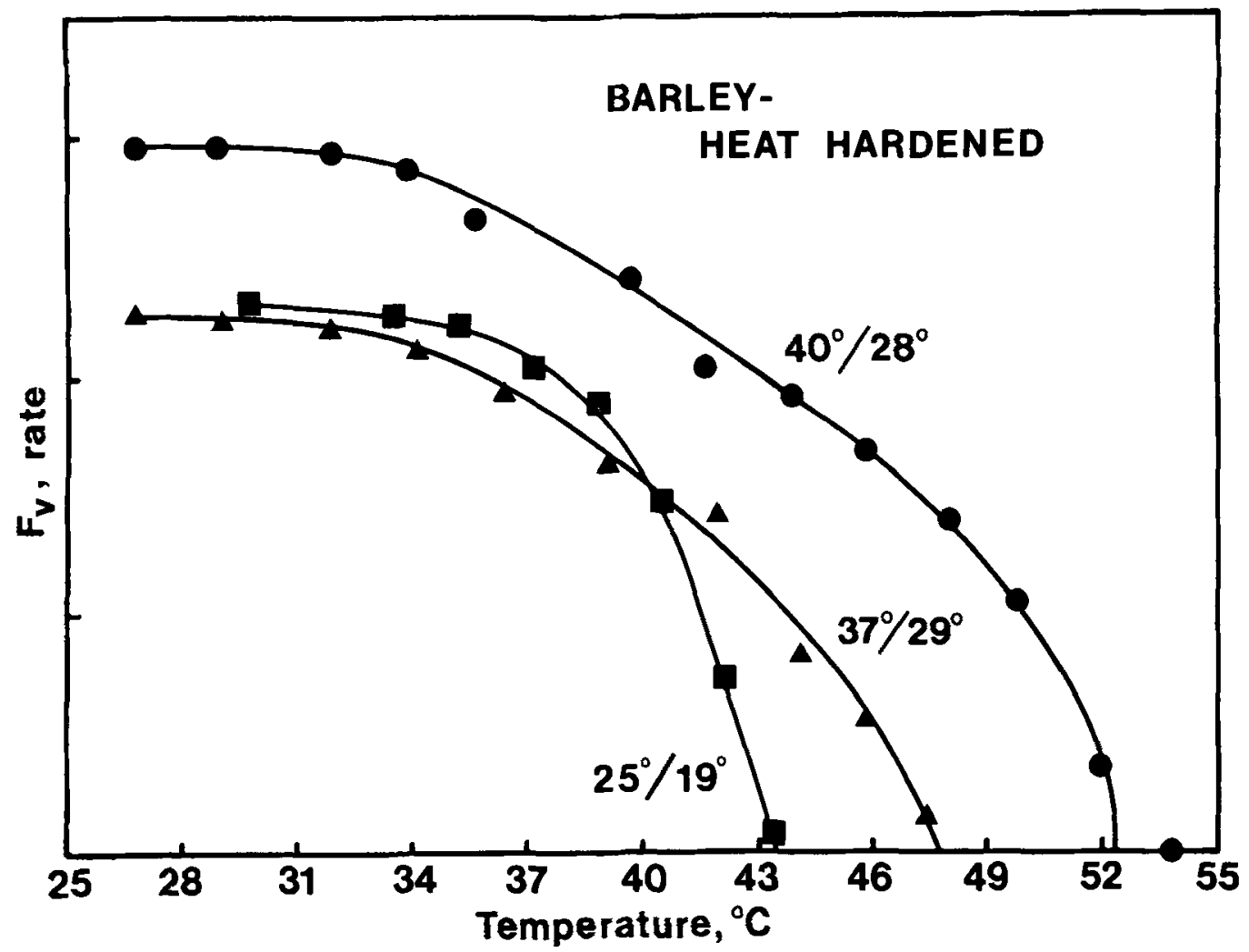

Figure 3. Measurement of heat hardening in barley leaf from the change in rate of the $F_{v}$ rise during heating.

Plants were first heat hardened as described in Materials and Methods and the excised primary leaf heated at $1{ }^{\circ} \mathrm{C}$ per min. Fluorescence measurements (irradiation time: $1.2 \mathrm{~s} ; 20 \mu \mathrm{E} \mathrm{m}^{-2} \mathrm{~s}^{-1}$ ) were taken with every 1.5 degree rise in leaf temperature. Values for unhardened leaves are divided by 2. 
Table II

Non-reversibility of the $F_{v}$ rise and reversibility of $F_{0}$ after heating.

Pea leaves were placed on a moist filter paper on an aluminium plate and covered with plastic film. Chlorophyll fluorescence induction kinetics were recorded for each leaf and the plate was then immersed in a water bath at the temperatures specified in the table. Heat treatment was terminated by immersing the plate in water at $21^{\circ} \mathrm{C}$ for $4 \mathrm{~min}$. Chlorophyll fluorescence was again recorded for each leaf and at various times thereafter during which time the temperature of the leaves was maintained at $21^{\circ} \mathrm{C}$. Each value is the average ( \pm standard error) for 8 leaves of estimations of the maximal rate of the $F_{v}$ rise (chart units $s^{-1}$ ) and $F_{0}$ (chart units).

\begin{tabular}{lccccc}
\hline \multirow{2}{*}{$\begin{array}{l}\text { Heat } \\
\text { treatment }\end{array}$} & \multirow{2}{*}{$\begin{array}{c}\text { Fluorescence } \\
\text { parameter }\end{array}$} & $\begin{array}{c}\text { Before } \\
\text { heating }\end{array}$ & & \multicolumn{3}{c}{ After heating } \\
\hline $40{ }^{\circ} \mathrm{C}, 10 \mathrm{~min}$ & Fy rise, rate & $43.4 \pm 2.6$ & $22.4 \pm 2.4$ & $20.8 \pm 1.8$ & $14.3 \pm 2.6$ \\
$41.5^{\circ} \mathrm{C}, 10 \mathrm{~min}$ & & $42.1 \pm 4.0$ & $5.5 \pm 0.4$ & $6.5 \pm 0.4$ & $3.4 \pm 0.8$ \\
$47{ }^{\circ} \mathrm{C}, 5 \mathrm{~min}$ & & $39.5 \pm 2.6$ & 0 & 0 & 0 \\
$40{ }^{\circ} \mathrm{C}, 10 \mathrm{~min}$ & $\mathrm{~F}_{\mathrm{O}}$ & $23.0 \pm 1.6$ & $20.1 \pm 1.0$ & $21.8 \pm 1.1$ & $18.2 \pm 2.6$ \\
$41.5^{\circ} \mathrm{C}, 10 \mathrm{~min}$ & & $24.4 \pm 2.5$ & $20.6 \pm 1.1$ & $24.1 \pm 1.8$ & $24.4 \pm 2.6$ \\
$47{ }^{\circ} \mathrm{C}, 5 \mathrm{~min}$ & & $27.6 \pm 2.6$ & $27.8 \pm 1.3$ & $25.9 \pm 2.6$ & $29.3 \pm 2.6$ \\
\hline
\end{tabular}

tures $(2,4,19,21,22,29)$. Figure 3 shows changes in the rate of rise of $F_{v}$ in barley primary leaves heat hardened using two different temperature regimes for growth. In the unhardened leaves from plants grown at $25^{\circ} \mathrm{C} / 19^{\circ} \mathrm{C}, \mathrm{F}_{\mathrm{v}}$ was undetectable above $43^{\circ} \mathrm{C}-44^{\circ} \mathrm{C}$, as shown previously for secondary leaves (Figures 1 and 2). This temperature was increase by $6{ }^{\circ} \mathrm{C}$ to $9^{\circ} \mathrm{C}$ in leaves from heat hardened plants (Figure 3). The increase in $F_{0}$ also occurred at a higher temperature in hardened compared with unhardened plants and can also be used as an indicator of heat hardening in barley, as has been demonstrated previously for other plants (4).

\subsection{Changes in $F_{v}$ and $F_{0}$ after heating}

The experiments described above and the other studies cited indicate that if fluorescence measurements are made during heating, either the decrease in $F_{v}$ or the increase in $F_{0}$ can be used to compare heat resistances in leaves of different species. However, $F_{0}$ may not be suitable to estimate heat damage using measurements made before and after a heat treatment (rather than during heating) as it has been reported (13) that the enhanced $F_{0}$ yield in heated Chlorella cells decreased when the temperature was again lowered. In Table II it can be seen that this was also the case for leaves; the heat induced increase in $F_{0}$ (Figure 2) was reversible after heating whereas the decrease in $F_{v}$ was not. In these experiments, three separate heat treatments were applied to different batches of pea leaves. These, in order of increasing temperature, produced a $48 \%, 87 \%$ and $100 \%$ inhibition of $F_{v}$ based on the decrease in the rate of the $F_{v}$ rise determined from fluorescence measurements made before and after ( 6 min readings) the heat treatments. There was no recovery in leaves maintained for an additional $30 \mathrm{~min}$ at $21^{\circ} \mathrm{C}$ after heating. Nor was there any long term recovery ( 22 hour readings) following the heat treatment. In contrast, values for $F_{0}$ showed little change following all three heat treatments. While only a small increase in $F_{0}$ would have taken place in the leaves heated at $40^{\circ} \mathrm{C}$ and $41.5^{\circ} \mathrm{C}, \mathrm{F}_{0}$ would have attained the maximum value during heating at $47^{\circ} \mathrm{C}$ for $5 \mathrm{~min}$ (Figure 2).

\section{DISCUSSION}

The Hill reaction in isolated chloroplasts is sensitive to heat (11), the heat labile site being located on the photooxidizing side of the photosystem II reaction centre $(12,28)$. Indeed, it appears to be one of the most heat sensitive 
reactions in green plant cells and temperatures around $40^{\circ} \mathrm{C}$ are often sufficient to cause thermal inactivation $(1,16,17,20,26)$. The inactivation of photosynthesis by temperatures around $40-45^{\circ} \mathrm{C}$ suggests that the oxygen evolving reaction is equally heat labile in intact tissue and essential cell functions such as respiration and maintenance of semipermeability of cell membranes are affected at considerably higher temperatures $(4,5,6)$.

The fluorescence of chlorophyll in vivo provides a sensitive non-destructive probe for photosynthetic electron transfer activity in algae and green plant tissue (18). Visible irradiation on a leaf results in a red fluorescence emission from chlorophyll that first rises rapidly, usually within $1 \mathrm{~ns}$, to the $F_{\mathrm{o}}$ level. This is fluorescence of constant yield at normal physiological temperatures, but the yield increases in heat damaged leaves (13). However, $F_{0}$ decreases again when the temperature is lowered (ref. 13 and Table II), even though the photosynthetic apparatus may have suffered irreparable heat damage, and as such it is not feasible to use measurements of $F_{0}$ as the basis of a screening method in which large numbers of leaf samples are heated for a fixed time, rapidly cooled and the effect of the heat treatment determined. The heat-induced increase in $F_{0}$ is very useful though in comparing the heat resistance of a limited number of samples during continuous heating as demonstrated for desert species by Armond et al. (3), Pearcy et al. (19), Schreiber and Berry (22) and Hetherington and SMILLIE (10), and for alpine, temperate and tropical species by SmiLlie and NotT (27).

After reaching $F_{0}$, the fluorescence yield continues to rise more slowly reaching a peak after about 1 to $2 \mathrm{sec}$. This fluorescence is of variable yield $\left(F_{v}\right)$ as it is responsive to changes in electron flow through photosystem II, being regulated by the redox state of photosystem II electron acceptors (7). Inhibition of a reaction on the photooxidizing side of photosystem II abolishes $F_{v ;}$ conversely, inhibition on the photoreducing side enhances $F_{v}$. High temperatures preferentially inactivate on the photooxidizing side of photosystem II and reduce the $F_{V}$ emission. Preferential inactivation on the photooxidizing side of photosystem II also occurs in plants grown at low light irradiances and then irradiated with intense visible light and in plants from the lowland tropics after exposure to a temperature of $0^{\circ} \mathrm{C}$. Consequently, changes in rate of the rise in $F_{v}$ in vivo can be used to assay for photoinhibition (8) and chilling injury $(9,25)$.

The results presented here demonstrate that changes in $F_{v}$ can also be used to follow the progress of heat damage in leaves during heating (Figures 1 and 2), to rank plants for heat resistance (Figure 2) and to ascertain the extent of heat acclimation or hardening (Figure 3 ). In the plants tested relative heat resistances were as expected, with barley and pea being the most sensitive, followed by bean and tomato, maize, and papaya. Further, the ranking obtained using $F_{v}$ agreed with that using $F_{0}$, a fluorescence parameter whose suitability for measurements of relative heat resistance in plants has been documented $(3,10,19,22,24,27)$. The rate of rise in $F_{v}$ has also been used to compare the heat resistances of non-hardened, heat hardened and dehardened spinach leaves (21).

The measurement of variable chlorophyll fluorescence in vivo would appear to be a suitable one on which to base a screening test for heat tolerance. Hill reaction activity and hence $F_{v}$ is not immediately reversible following thermal inactivation (Table II), and thus heat damage can be assessed by determining $F_{v}$ before and after a standardized heat treatment. The temperatures resulting in a decreased $F_{v}$ are those sometimes experienced by plants growing in hot climates and are lower than the temperatures required to change $F_{0}$. The discrimination of heat resistance among species is slightly better using $F_{v}$ compared with $F_{o}$ (Table I). In any screening application, recording the rate of the maximal rise in $F_{v}$ rather than the magnitude of $F_{v}$ before and after heating may be preferable since it would not be necessary to wait until the fluorescence yield reaches a maximum and this would shorten the measurement time required for each sample. Using a portable fluorometer of the types described by Schreiber et al. (23) and MELCAREK et al. (15) the reading for each leaf sample could be completed within a few seconds.

\section{ACKNOWLEDGEMENTS}

We thank RoByn NotT for her excellent technical assistance. 


\section{REFERENCES}

1. Ageeva, O. G.: Effects of light on thermostability of Hill reaction in pea and spinach chloroplasts. Photosynthetica 11, 1-4 (1977)

2. Alexandrov, V. Ya: Cytophysiological and cytoecological investigations of heat resistance of plant cells toward the action of high and low temperature. Quart. Rev. Biol. 39, 35-77 (1964)

3. ARmond, P. A., U. Schreiber \& O. Buörkman: Photosynthetic acclimation to temperature in the desert shrub, Larrea divaricata. II. Lightharvesting efficiency and electron transport. Plant Physiol. 61, 411-415 (1978)

4. Berry, J. \& O. Buörkman: Photosynthetic response and adaptation to temperature in higher plants. Ann. Rev. Plant Physiol. 31, 491-543 (1980)

5. Björkman, O.: Thermal stability of the photosynthetic apparatus in intact leaves. Carnegie Inst. Wash. Yearb. 74, 748-751 (1975)

6. Björkman, O., J. Boynton \& J. Berry: Comparison of the heat stability of photosynthesis, chloroplast membrane reactions, photosynthetic enzymes, and soluble protein in leaves of heatadapted and cold-adapted $\mathrm{C}_{4}$ species. Carnegie Inst. Wash. Yearb. 75, 400-407 (1976)

7. Bradbury, M. \& N. R. BaKer: Energy distribution in the photochemical apparatus of leaves during the $\mathrm{P}$ to $\mathrm{T}$ phase of the fluorescence quenching curve. Proc. 5th Int. Photosynthesis Congr. In press. (1981)

8. Critchley, C. \& R. M. Smillie: Leaf chlorophyll fluorescence as an indicator of high light stress (photoinhibition) in Cucumis sativus $L$. Aust. J. Plant Physiol. 8, 133-141 (1981)

9. Gibbons, G. C. \& R. M. Smillie: Chlorophyll fluorescence photography to detect mutants, chilling injury and heat stress. Carlsberg Res. Commun. 45, 269-282 (1980)

10. Hetherington, S. E. \& R. M. Smiluie: Tolerance of Borya nitida, a poikilohydrous angiosperm, to heat, cold and high light stress in the hydrated state. Submitted to Planta (1982)

11. Holt, A. S. \& C. S. French: The photochemical production of oxygen and hydrogen ion by isolated chloroplasts. Arch. Biochem. 9, 25-43 (1946)

12. Katoh, S. \& A. San Pietro: Ascorbatesupported NADP photoreduction by heated Euglena chloroplasts. Arch. Biochem. Biophys. $122,144-152$ (1967)

13. LAVOREL, J.: On a relation between fluorescence and luminescence in photosynthetic system. In: Progress in Photosynthesis Research. Vol. II. (H. Metzner, ed.) pp. 883-898 (1969)

14. McWilliam, J. R. \& P. J. Ferrar: Photosynthe- tic adaption of higher plants to thermal stress. In: Mechanisms of regulation of plant growth (R. $L$. Bielski, A. R. Ferguson \& M. M. Cresswell, eds.) Bulletin 12, Royal Soc. New Zealand, Wellington, 467-476 (1974)

15. Melcarek, P. K., L. G. Cernohlavek \& G. N. Brown: A solid state device for the simultaneous measurement of prompt and delayed fluorescence induction transients in leaves. Anal. Biochem. 82, 473-484 (1977)

16. Molotkovsky, Y. G. \& I. M. Sheskova: The influence of heating on the morphology and photochemical activity of isolated chloroplasts. Biochem. Biophys. Res. Commun. 20, 411-415 (1965)

17. Mukohata, Y., T. Yagi, M. Higashida, K. Shinozaki \& A. Matsuno: Biophysical studies on subcellular particles VI. Photosynthetic activities in isolated spinach chloroplasts after transient warming. Plant \& Cell Physiol. 14, 111-118 (1973)

18. Papageorgiou, G.: Chlorophyll fluorescence: An intrinsic probe of photosynthesis. In: Bioenergetics of Photosynthesis (Govindjee, ed.) Academic Press, New York, pp. 319-371 (1975)

19. Pearcy, R. W., J. A. Berry \& D. C. Fork: Effects of growth temperature on the thermal stability of the photosynthetic apparatus of Atriplex lentiformis (torr.) Wats. Plant Physiol. 59, 873-878 (1977)

20. Santarius, K. A.: Sites of heat sensitivity in chloroplasts and differential inactivation of cyclic and non-cyclic photophosphorylation by heating. J. Thermal Biology 1, 101-107 (1975)

21. Santarius, K. A. \& M. Müller: Investigations on heat resistance of spinach leaves. Planta 146, 529-538 (1979)

22. Schreiber, U. \& J. A. Berry: Heat-induced changes of chlorophyll fluorescence in intact leaves correlated with damage of the photosynthetic apparatus. Planta 136, 233-238 (1977)

23. Schreiber, U., L. Groberman \& W. Vidaver: Portable, solid-state fluorometer for the measurement of chlorophyll fluorescence induction in plants. Rev. Sci. Instrum. 46, 538-542 (1975)

24. Smiluie, R. M.: Coloured components of chloroplast membranes as intrinsic membrane probes for monitoring the development of heat injury in intact tissue. Aust. J. Plant Physiol. 6, 121-133 (1979)

25. Smillie, R. M.: The useful chloroplast: a new approach for investigating chilling stress in plants. In: Low Temperature Stress in Crop Plants (J. M. Lyons, D. Graham \& J. K. Raison, eds.) Academic Press, New York, pp. 187-202 (1979) 
R. M. Smillie \& G. C. Gibbons: Heat tolerance hardening

26. Smillie, R. M., C. Critchley, J. M. Bain \& R. NorT: Effect of growth temperature on chloroplast structure and activity in barley. Plant Physiol. 62, 191-196 (1978)

27. Smillie, R. M. \& R. Nott: Heat injury in leaves of alpine, temperate and tropical plants. Aust. J. Plant Physiol. 6, 135-141 (1979)

28. Yamashita, T. \& W. L. Butler: Inhibition of chloroplasts by UV-irradiation and heat-treatment. Plant Physiol. 43, 2037-2040 (1968)

29. YARWOOD, C. E.: Adaption of plants and plant pathogens to heat. In: Molecular Mechanisms of Temperature Adaption (C. L. Prosser, ed.) American Association for the Advancement of Science, Publ. No. 84: Washington, D.C. pp. 75-89 (1967) 